\title{
METABOLIZABLE ENERGY OF RATION ADDED WITH NANOCAPSULE OF TURMERIC EXTRACT ON BROILER CHICKEN
}

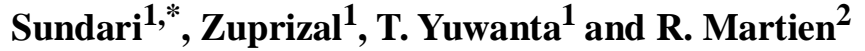 \\ ${ }^{1}$ Faculty of Animal Science, Gadjah Mada University, \\ Jl. Fauna 3, Bulaksumur Yogyakarta 55281 - Indonesia. \\ *Permanent Address: Faculty of Agroindustry, Mercu Buana University, \\ Jl. Wates Km 10, Sedayu-Bantul 55753 - Yogyakarta \\ ${ }^{2}$ Departement of Pharmaceutics, Faculty of Pharmacy, Gadjah Mada University, \\ Sekip Utara Yogyakarta 55281 - Indonesia \\ Corresponding E-mail: sundari_umby@yahoo.com
}

Received January 11, 2013; Accepted Februari 24, 2013

\begin{abstract}
ABSTRAK
Penelitian ini bertujuan untuk mengembangkan formulasi nanokapsul menggunakan ekstrak kunyit dan kitosan sebagai polimer serta sodium-tripolifosfat sebagai cross linker, untuk dipelajari kemampuannya dalam meningkatkan energi metabolis sejati ransum ayam broiler. Metode yang digunakan dalam formulasi nanokapsul adalah gelasi ionik. Metode untuk mengevaluasi energi metabolis sejati menggunakan total koleksi. Empat puluh delapan ekor ayam broiler dengan bobot badan rata-rata $900 \mathrm{~g}$, dibagi secara acak ke dalam 8 perlakuan (satu perlakuan dipuasakan dan 7 perlakuan diberi ransum dengan penambahan feed additive), masing-masing enam ekor. Ayam dipuasakan sehari pada sebelum dan sesudah ayam diperlakukan dengan ransum, bobot dan kandungan nitrogen serta energy bruto pakan yang dikonsumsi serta ekskreta/ digesta ileum yang dikeluarkan diketahui untuk menghitung energi metabolis sejati. Telah ditemukan bahwa energy metabolis sejati ransum basal yang ditambah nanopartikel $0,1 \%(3370,66 \mathrm{kcal} / \mathrm{kg})$ nyata lebih tinggi $(\mathrm{P}<0,05)$ dibanding ransum basal $(3214,85 \mathrm{kcal} / \mathrm{kg})$ dan ransum yang lainnya. Dapat disimpulkan bahwa formulasi nanokapsul menggunakan ekstrak kunyit dengan kitosan industri sebagai polimer dan sodium-tripolifosfat sebagai cross-linker berpotensi sebagai feed additive alternatif untuk meningkatkan energi metabolis sejati ransum pada ayam broiler.

Kata kunci: energi-metabolis-sejati, nanokapsul, ekstrak kunyit, kitosan, ayam broiler
\end{abstract}

\begin{abstract}
This study was aimed to develop nanoparticle formulation using turmeric extract and industrial chitosan as the polymer and sodium-tripolyphosphate as cross linker, to evaluate its ability to improve true metabolizable energy on broiler chicken. Forty eight of broiler chickens with an average body weight of $900 \mathrm{~g}$, were randomly divided into 8 treatments (one treatment was fasted and 7 were fed ration plus feed additive), containing six birds per treatment. The formulation of nanoparticle in this study used ionic gelation method. Method used to evaluate the metabolizable energy was total collection. Chickens were fasted one day before and after they were treated with rations. Nitrogen, gross energy and total weight of feed and excreta or ileal digesta released were analyzed to calculate the true metabolizable energy of the ration. It was found that the basal ration added with nanocapsule $0.1 \%$ had true metabolizable energy $(3370.66 \mathrm{kcal} / \mathrm{kg})$ significantly higher $(\mathrm{P}<0.05)$ than basal ration $(3214.85$ $\mathrm{kcal} / \mathrm{kg}$ ). The result of this study concluded that formulation of nanocapsule using turmeric extract and industrial chitosan as the polymer and sodium-tripolyphosphate as cross linker was potential to increase true metabolizable energy so it can be an alternative for broiler chicken feed additive.

Keywords: true-metabolizable-energy, nanocapsule, turmeric extract, chitosan, broiler chicken
\end{abstract}




\section{INTRODUCTION}

Antibiotics has facilitated the efficient production of poultry, allowing the consumer to purchase at a reasonable price on high quality of meat and eggs (Donoghue, 2003). A wide range of antibiotics are used in poultry not only to treat disease but also to maintain health, promote growth and enhance feed efficiency (Gaudin et al., 2004). In particular, broiler chickens often grow rapidly with antibiotics to attain maximum weight within a short period of time (Nonga et al., 2009). The uncontrolled and unlimited use of these antibiotics however may lead to the accumulation of undesirable residues in the treated animals and their products (Wachira et al., 2011).

Controversy over the use of a fore mentioned antibiotics and high-energy rations call for an effort to find a feed additive from natural ingredients that have a potential to substitute the function of antibiotics to enhance feed efficiency included to improve metabolizable energy of the ration. One potential herbal medicine in Indonesia is curcumin which is the main active ingredient of turmeric rhizome. Several studies in vitro and in vivo have shown that turmeric can be as: antibacterial, anti-inflammatory, antitoxic, antihiperlipid, antioxidant and anticancer, but curcumin has low bioavailability (low solubility, poor absorption, fast pass, high rates of metabolism in the gut cells, rapid elimination) (Anand et al., 2007). One reason for the low bioavailability of curcumin is water insoluble at acidic or neutral $\mathrm{pH}$, and this causes absorption difficulty (Maiti et al., 2007). This obstacle can be solved by the development of nanoparticle technology to improve drug delivery profile, especially for the less bioavailable chemical. Therefore, the application of curcumin needed polymers that are capable of carrying and being delivered to be absorbed properly, such as chitosan by nanotechnology (nanoencapsulation).

Chitosan is a natural biopolymer obtained by alkaline deacetylation of chitin /crab shell (Hejazi and Amiji, 2003). Chitosan has various excellent properties as biocompatible, bio-degradable, low toxic and not immunogenic. Chitosan is widely used together with TPP (sodiumTripolyphosphate) polyanion in various nanoparticle formulation studies by ionic gelation method. Ionic gelation method is engaged to the forming of the complex by the two oppositely charged structures which then form nanoparticle gel. Ionic gelation is a very simple and easy preparation method (Racovita et al., 2009). This molecular weight takes influence in its solubility and viscosity. Short chain chitosan is dissolved easily in acidic organic solvents such as acetic acid, citric acid, and tartaric acid (Mao et al., 2009).

This study was aimed to develop the nanoparticle formulation using turmeric extract with industrial chitosan as the polymer and sodium-tripolyphosphate as cross linker, to evaluate its ability as a feed additive for antibiotics substitute to enhance feed efficiency, specially to improve true metabolizable energy of ration in broiler chickens.

\section{MATERIALS AND METHODS}

The nanocapsule $(840 \pm 30.90 \mathrm{~nm})$ was created by ionic gelation method using extracted turmeric:chitosan:TPP (sodium-tripolyphosphate) $=2 \%: 2 \%: 1 \%(\mathrm{w} / \mathrm{v})$. Nanocapsule were produced from: (1). Turmeric extracted $(20 \mathrm{~g})$ dissolved in $100 \mathrm{~mL}$ ethanol $96 \%$ then added with chitosan (20 g) dissolved in $800 \mathrm{~mL}$ buffer acetic $\mathrm{pH} 4$ by magnetic stirrer for 20 minutes, and then added with TPP (10 g) was dissolved in $100 \mathrm{~mL}$ aquades by magnetic stirrer for 20 minutes. Furthermore, the dispersed mixture was precipitated, filtered and oven-dried at $50^{\circ} \mathrm{C}$ and ground into powder to be mixed in the ration.

A total of 48 broiler chickens weighing \pm $900 \mathrm{~g}$ were placed in individual cages equipped with feed and water. Provision of feed additive has been done on 8 groups of chickens (1 group was fasted and 7 groups having feeding treatments as shown in Table 2) with 6 birds per group (Donkoh and Attoh-Kotoku, 2009). A method for testing the metabolizable energy was by total collection method (modification from Revington et al., 1991 and Adeola et al., 1997). The $7^{\text {th }}$ day of adaptation period was followed by the total collection. All chickens were fasted but drinking water was provided ad libitum on the first day of total collection. On the second day, 7 groups of chickens were fed basal rations (Table 1) plus feed additive (Table 2) and 1 group remained fasting to test endogenous $\mathrm{N}$. On the third day, all chickens were fasted again. Excreta were collected by plastic bag from the second to the third day, completed 48 hours. On the fourth day, all chickens were slaughtered to take the ileal digesta.

Samples of feed and all of excreta or ileal 
Table 1. Composition and Nutrient Contents of Basal Ration (BR)*

\begin{tabular}{lc}
\hline \multicolumn{1}{c}{ Feed Ingredients } & Percentage \\
\hline Milled yellow corn & 52.00 \\
Rice bran & 12.50 \\
Soybean meal & 19.50 \\
Fish meal & 9.50 \\
Palm oil & 5.10 \\
Limestone & 0.30 \\
NaCl salt & 0.40 \\
Top mix mineral-vitamin ** & 0.40 \\
L-Lysine HCl & 0.20 \\
DL Methionine & 0.10 \\
TOTAL & 100.00 \\
Nutrient Contents & \\
Crude protein (\%) & 20.13 \\
Metabolizable Energy (kcal/kg) & 3201.77 \\
Crude fat (\%) & 5.41 \\
Crude fiber (\%) & 3.35 \\
Calcium (\%) & 0.90 \\
Available phosphorus (\%) & 0.43 \\
Lysine (\%) & 1.29 \\
Methionine (\%) & 0.5 \\
\hline * Standard nutrient requirements of broiler chickens \\
3-6 weeks (NRC, 1994): 20\% protein; $1.0 \%$ Lys; \\
0.38\% Met; energy 3200 kcal/kg, 0.9\% Ca, \\
0.35\% P.av \\
** Composition per kilogram of top mix mineral- \\
vitamin : Ca 32.5\%; P 10.0\%; Fe 6.0 g; Mn 4 g; \\
Iod 0.075 g; Zn 3.75 g; vit B $_{12}$ 0.5 mg; vit $\mathrm{D}_{3}$ \\
50000 IU. \\
\end{tabular}

digesta were removed, weighed, dried and further ground to pass $1 \mathrm{~mm}$ sieve, then swabbed, included in labeled plastic bags and stored at $4^{\circ} \mathrm{C}$ for nitrogen and calorie analysis use. Gross energy was analyzed by bomb calorimeter (Gallenkamp auto bomb) and nitrogen contents of feed and excreta or ileal digesta was analyzed by AOAC (2006) to determine the effect of addition of nanocapsule feed additives on the true metabolizable energy of the ration. The AME
(Apparent Metabolizable Energy), AMEn (nitrogen corrected AME), TME (True Metabolizable Energy), and TMEn (nitrogen corrected TME) of the test were calculated as follows (Adeola et al., 1997): AME $=(\mathrm{EI}-\mathrm{EO}) \div$ FI; $\mathrm{AMEn}=\mathrm{AME}-(8.22 \times \mathrm{ANR} \div \mathrm{FI})$, TME $=$ $\mathrm{AME}+(\mathrm{FEL} \div \mathrm{FI}) ; \mathrm{TMEn}=\mathrm{AMEn}+(\mathrm{FEL} \div \mathrm{FI})$ $-(8.22 \times \mathrm{FNL} \div \mathrm{FI})$, where EI is gross energy intake (kilocalories); EO is gross energy output in the excreta (kilocalories); FI is feed intake (grams); ANR is apparent nitrogen retention (grams) calculated as the difference between nitrogen intake and nitrogen output; FEL is the fasting energy loss from the group of the feeddeprived chickens (kilocalories); and FNL is fasting nitrogen loss from the group of feeddeprived chickens (grams).

The data metabolizable energy (AME, TME, AMEn and TMEn) was analyzed by analysis of variance and further significant differences used Least Significant Difference by SPSS-16 computer program .

\section{RESULTS AND DISCUSSION}

Metabolizable energy of rations added feed additive are shown in Table 2. The Value of TME of R1 that was based on research (Table 2) was equal to the value of $\mathrm{R} 1$ calculations based on the energy content of the feedstuff (Table 1 is 3202 $\mathrm{kcal} / \mathrm{kg}$ ). This shows that the method used to evaluate energy metabolizable is good. In granting BR plus NP $0.1 \%$ (R4) provided the greatest value of TME (3370.66) that differ significantly ( $\mathrm{P}$ $<0.05)$ than the other rations included R1, R2, R3, R5, R6, R7 and R8, while R3 (BR plus turmeric extract $0.1 \%$ ) gives the smallest value of ME. The administration R4 with $0.1 \%$ nanocapsule contained $0.04 \%$ turmeric extract, $0.04 \%$ chitosan and $0.02 \%$ STTP, produced TME that was greater value than the provision of R3 containing $0.1 \%$ turmeric extract. This provides evidence that the provision of nanocapsul was more effective to increase metabolizable energy ration. This is because in R4 nanochitosan is able to bind curcumin and take it, open the tigh-junction so that it can be absorbed better and get into the body cells, ionic bonding between curcumin and chitosan will be separated by a protease and lizozim that exist in the cell fluid. STTP has a negative charge that is able to bind chitosan that had a positive charge to form more robust capsule shell which can protect the chitosan from degradation by acid and protease in the stomach. 
Table 2. Metabolizable Energy (AME, TME, $\mathrm{AME}_{\mathrm{n}}$ and $\mathrm{TME}_{\mathrm{n}}$ ) of Ration Added feed additive on Broiler Chickens (kcal/kg)

\begin{tabular}{|c|c|c|c|c|}
\hline \multirow{2}{*}{ reatments } & AME & TME & $\mathrm{AME}_{\mathrm{n}}$ & $\mathrm{TME}_{\mathrm{n}}$ \\
\hline & \multicolumn{4}{|c|}{ (kcal/kg) } \\
\hline R1, Basal Ration (BR) & $3184.21^{\mathrm{e}} \pm 44.84$ & $3214.85^{\mathrm{e}} \pm 44.84$ & $3198.19^{\mathrm{e}} \pm 44.75$ & $3228.05^{\mathrm{e}} \pm 44.75$ \\
\hline $\mathrm{R} 2, \mathrm{BR}+$ Chitosan $0.1 \%$ & $3021.23^{\mathrm{c}} \pm 76.72$ & $3051.87^{\mathrm{c}} \pm 76.72$ & $3036.40^{\mathcal{C}} \pm 76.66$ & $3066.25^{\mathrm{c}} \pm 76.66$ \\
\hline R3, BR + Turmeric E. $0.1 \%$ & $2871.35^{\mathrm{a}} \pm 23.14$ & $2901.99^{a} \pm 23.14$ & $2885.86^{\mathrm{a}} \pm 23.85$ & $2915.72^{\mathrm{a}} \pm 23.85$ \\
\hline R4, BR + Nanocapsule $0.1 \%$ & $3340.02^{\mathrm{f}} \pm 44.90$ & $3370.66^{\mathrm{f}} \pm 44.90$ & $3352.02^{\mathrm{f}} \pm 44.94$ & $3381.87^{\mathrm{f}} \pm 44.94$ \\
\hline R5, BR + Nanocapsule $0.2 \%$ & $3200.61^{\mathrm{e}} \pm 34.90$ & $3231.24^{\mathrm{e}} \pm 34.90$ & $3211.74^{\mathrm{e}} \pm 35.09$ & $3241.59^{\mathrm{e}} \pm 35.09$ \\
\hline R6, BR + Nanocapsule $0.3 \%$ & $2964.11^{\mathrm{b}} \pm 21.80$ & $2994.75^{\mathrm{b}} \pm 21.80$ & $2976.59^{\mathrm{b}} \pm 21.43$ & $3006.45^{\mathrm{b}} \pm 21.43$ \\
\hline R7, BR + Nanocapsule $0.4 \%$ & $2944.16^{\mathrm{b}} \pm 9.24$ & $2974.79^{\mathrm{b}} \pm 9.24$ & $2954.10^{\mathrm{b}} \pm 9.14$ & $2983.96^{\mathrm{b}} \pm 9.14$ \\
\hline R8, BR + Nanocapsule $0.5 \%$ & $3119.14^{d} \pm 37.69$ & $3149.74^{\mathrm{d}} \pm 37.69$ & $3135.79^{d} \pm 37.62$ & $3165.64^{d} \pm 37.62$ \\
\hline
\end{tabular}

AME: apparent metabolizable energy, $\left(\mathrm{AME}_{\mathrm{n}}\right)$ : nitrogen corrected AME; TME (True Metabolizable Energy), and TMEn (nitrogen corrected TME)

The average value in the same column with different superscripts indicate significant differences $(\mathrm{P}<0.05)$.

Turmeric E. = Ethanol Extract of Turmeric, Nanocapsule is Nanocapsule of turmeric extracted by ethanol $96 \%$ and processed nanoencapsulation by ionic gelation method with chitosan as polymer and Sodium tripolyphosphate as cross linker.

While the turmeric extract /curcumin in intestines was no protect and unstable / degraded at neutral to alkaline $\mathrm{pH}$. On the other hand, in the study of curcumin digestibility in R3 was $53.46 \%$ and R8 was $77.23 \%$. Besides that, nanocurcumin, STTP, and nanochitosan have a function as antibiotics to reduce the population of pathogenic bacteria in gut.

The above items in accordance with the opinion of Sinaga et al. (2010) which stated that curcumin may affect the tone and contraction of the intestine, giving the low-dose will accelerate intestinal tone, but at high doses it will slow down and even stop the contractions of the small intestine. However, in the right dose, it will cause spontaneous contraction, so that the digestibility and absorption of food will increase. In mice and rabbits, curcumin can stimulate an increase in relaxation intestine resulting longer food in the small intestine and stimulates the secretion of hormones from the Brunner glands of the small intestine (Sinaga et al., 2010). This is in line with an opinion that curcumin may increase the secretion of bile and pancreatic lipase activity, increased amylase, trypsin and chemotrypsin
(Chattopadhyay et al., 2004). The same finding was reported by Rao et al. (2003) that curcumin increases spending stimulation of pancreatic enzymes and small intestine and decreased intestinal peristalsis, thereby providing nutrients absorption of products of digestion more. Pigs given $4 \mathrm{mg}$ curcuminoids / $\mathrm{kg}$ body weight showed the highest protein digestibility, as giving the right dose curcuminoids can increase the digestibility of nutrients especially proteins, as curcuminoids to stimulate the secretion of hormones from the glands of Brunner in the intestinal wall, then this is the hormone which will stimulate increased secretion of digestive enzymes from the pancreas gland by enzymes in the small intestine enterokinase converted into enzyme trypsin which in turn can increase the digestibility of protein (Sinaga and Silalahi, 2012). Report of Dono (2012) showed that supplementation of turmeric powder $10 \mathrm{~g} / \mathrm{kg}$ diet led the increasing of energy digestibility, the apparent metabolizable energy (AME), nitrogen corrected AME (AMEn), and total tract nitrogen retention. On the other hand, in the study of protein digestibility in R3 was $57.08 \%$ and R4 
was $62.62 \%$. Antimicrobial properties from curcumin, chitosan and STTP might help reducing the competition for available nutrients with the host, stimulate the growth of absorptive cells in the small-intestinal mucosa, and trigger the secretion of innate digestive enzymes. These enhancements should create a gut environment that is more suitable for optimal nutrient digestion and absorption, resulting in a greater nutrient and energy utilization efficiency.

The results of ME (Table 2) that are given basal ration plus chitosan $0.1 \%(\mathrm{R} 2)$ were smaller significantly $(\mathrm{P}<0.05)$ than $\mathrm{R} 1$ because $\mathrm{R} 2$ had crude fat digestibility (43\%) that was lower than others. Metabolizable energy derived from fat, protein and carbohydrates. Lipid is the largest contributor to energy. This is in line with an opinion stated that chitosan from shrimp shell can bind fats (FBC) averaging $416.5 \%$ for soybean oil, $503 \%$ for corn oil, and $400.8 \%$ for the sesame oil, and FBC value of original shrimp shell chitosan is higher than the original commercial FBC crab shell chitosan (Sigma Co.) (Sofia et al., 2010). It is not as same as the opinion of Shi et al. (2005) that the optimum growth and feed conversion of broiler obtained by the addition of 0.5 to $1.0 \mathrm{~g}$ chitosan $/ \mathrm{kg}$ feed, equivalent metabolizable energy yield from 0.05 to $0.1 \%$ in the diet has not changed. Ration that was added with nanocapsule $0.1 \%$ (R4) has a $63.46 \%$ fat digestibility. Most chitosan binds with curcumin and STTP from nanocapsule off, so there is little chitosan in the small intestine to bind dietary fat. There is also a free TPP that had alkaline $\mathrm{pH}$, and will stimulate the secretion of lipase to digest fat. Both allow the energy digestibility in R4 was greater than the others, beside the increase of protein digestibility.

\section{CONCLUSIONS}

The nanocapsule of turmeric extract gave new hope as an alternative feed additive to replace antibiotic growth promoters. It was evident that the addition of $0.1 \%$ of nanocapsule in ration could improve true metabolizable energy of the ration.

\section{REFERENCES}

Adeola, O., D. Ragland and D. King. 1997. Feeding and excreta collection techniques in metabolizable energy assay for ducks. Poult. Sci. 76:728-732.
Anand, P., A.B. Kunnumakkara, R.A. Newman, and B.B. Aggarwal. 2007. Bioavailability of Curcumin: Problems and Promises. Reviews. Mol. Pharmaceutics. 4(6):807-818.

AOAC. 2006. Official Methods of Analysis. $18^{\text {th }}$ ed. Association of Analytical Communities. Washington DC. USA.

Chattopadhyay, I., K. Biswas, U. Bandyopadhyay and R.K. Banerjee. 2004. Turmeric and curcumin: Biological actions and medicinal applications. Current Science. 87(1):44-53.

Dono, N.D., 2012. Nutritional strategies to improve enteric health and growth performance of poultry in the post antibiotic era. Dissertation, the college of medical, veterinary and life science, University of Glasgow. UK.

Donkoh, A. and V. Attoh-Kotoku. 2009. Nutritive value of feedstuffs for poultry in Ghana: chemical composition, apparent metabolizable energy and ileal amino acid digestibility. Livest. Res. Rural Dev. 21(3):110 .

Donoghue, D. J. 2003. Antibiotic residues in poultry tissues and eggs: Human health concerns? Poult. Sci. 82: 618-621.

Gaudin, V., P. Maris, R. Fusetier, C. Ribouchon, N. Cadieu and A. Rault. 2004. Validation of a microbiological method: The star protocol, a five plate test for screening of antibiotic residues in milk. Food Add. Cont. 21(5): 422-433.

Hejazi, R. and M. Amiji. 2003. Chitosan-based gastro intestinal delivery systems. J Controlled Release. 89: 151-165.

Maiti, K., K. Mukherjee, A. Gantait, B.P. Saha and P.K. Mukherjee. 2007. Curcumin phospholipid complex: Preparation, therapeutic, evaluation and pharmacokinetic study in rats. Int. J. Pharm. 330(1-2): 155-63.

Mao S, W Sun and T Kissel. 2009. Chitosanbased formulations for delivery of DNA and siRNA. Adv. Drug Delivery Reviews. 62:1227.

Nonga, H.E., M. Mariki, E.D. Karimuribo and R.H. Mdegela. 2009. Assessment of antimicrobial usage and antimicrobial residues in broiler chickens in Morogoro Municipality, Tanzania. Pakistan J. Nutr. 8(3): 203-207.

NRC. 1994. Nutrient Requirements of Poultry: Ninth Revised Edition. National Academiy Press, Washington, DC.

Rao, R.R., K.Platel, K.Srinivan. 2003. In vitro 
influence of spices and spice-active principles on digestive enzymes of rat pancreas and small intestine. Nahrung. 47(6): 408-412.

Racoviță, S., S. Vasiliu, M. Popa and C Luca. 2009. Polysaccharides based on micro and nanoparticles obtained by Ionic gelation and their Applications as drug delivery systems. Revue Roumaine de Chimie 54: 709-718.

Revington, W.H., N. Acar and E.T. Moran JR, 1991. Research Note: Cup versus tray excreta collection in metabolizable energy assays. Poult. Sci. 70(5):1265-1268.

Sinaga S., D.T.H. Sihombing, M. Bintang and Kartiarso. 2010. Curcumin dalam ransum babi sebagai pengganti antibiotik sintesis untuk perangsang pertumbuhan. Forum Pascasarjana. 33(2):123-131.

Sinaga, S. and M. Silalahi. 2012. Pengaruh pemberian berbagai dosis kurkominoid terhadap kecernaan protein, efisiensi protein dan kecepatan laju makanan dalam sistem pencernaan babi finisher. Jurnal Penelitian Pertanian Terapan. 11(2):1-14.

Shi, B.L., D.F. Li, X.S. Piao and S.M. Yan. 2005. Effect of chitosan on growth performance and energy and protein utilization in broiler chickens. British Poult. Sci. 46(4):516-519.

Sofia, I., Pirman, and Z. Haris. 2010. Karakterisasi fisiokimia dan fungsional kitosan yang diperoleh dari limbah cangkang udang windu. Jurnal Teknik Kimia Indonesia 9(1):11-18.

Wachira, W.M., A. Shitandi and R. Ngure, 2011. Determination of the limit of detection of penicillin $\mathrm{G}$ residues in poultry meat using a low cost microbiological method. Int. Food Res. J. 18(3): 1203-1208. 